\title{
Biostratigraphy of the Cenomanian-Turonian boundary in the Eastern Carpathians (Dâmboviţa Valley): preliminary observations
}

\author{
Claudia G. CETEAN ${ }^{*}$, Ramona BĂLC' ${ }^{1}$ Michael A. KAMINSKI ${ }^{2} \&$ Sorin FILIPESCU1 \\ ${ }^{1}$ Department of Geology, „Babeş-Bolyai” University, Kogălniceanu 1, 400084, Cluj Napoca, Romania \\ ${ }^{2}$ Department of Earth Sciences, University College London, Gower Street, London WC1E 6BT, U.K.
}

Received June 2007; accepted May 2008

Available online 25 August 2008

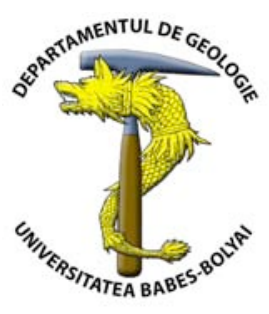

\begin{abstract}
Planktonic and benthic foraminiferal assemblages from an Upper Albian to Lower Turonian interval in the East Carpathians were investigated in a well and in an outcrop from the Stoeneşti - Cetăţeni area (Dâmbovița Valley), Romania. The benthic foraminiferal extinction that occurred at the Cenomanian/Turonian boundary and the first stage of the faunal recovery are documented here for the first time in the Romanian Carpathians. Bioevents and changes in the foraminiferal record from this area show that low oxygen conditions occured already in the Late Cenomanian, as suggested by the presence of radiolarian-rich shales. Impoverished assemblages of small, thin walled agglutinated foraminifera are present in the lowermost Turonian after the benthic-free interval corresponding to the "Bonarelli Level". Calcareous nannofossils are also documented from this level in the well from the Stoeneşti locality.
\end{abstract}

Key words: Eastern Carpathians, foraminifera, calcareous nannofossils, biostratigraphy, Cenomanian/Turonian boundary, low oxygen.

\section{INTRODUCTION}

One of the Cretaceous intervals of widespread anoxia resulting in the global deposition of carbon-rich sediments is Oceanic Anoxic Event 2 (OAE2), which occurred close to the Cenomanian/Turonian boundary (Schlanger and Jenkins, 1976). Carbon-rich sediments and associated microfaunal changes have now been documented from numerous DSDP and ODP sites (e.g., Kuhnt, 1992) and onshore sections worldwide (e.g., Kaiho, 1994), and reflect a major perturbation of the global carbon cycle.

The Cenomanian/Turonian Boundary Event is well documented in southern Europe where it is referred to as the "Bonarelli Level" (Arthur and Premoli-Silva, 1982; Luciani and Cobianchi, 1999; Scopelliti et al., 2004; Gräfe, 2005) and in northern and western Europe (Ernst et al., 1984; Hilbrecht et al., 1996; Svobodá et al., 2004; Bakk, 2006). However, relatively few studies deal with the benthic foraminiferal turnover over this interval (Leckie, 1985; Leary and Peryt, 1991; Kuhnt, 1992; Coccioni et al., 1995; Paul et al., 1999; Peryt, 2004). Many of these studies only provide information on bathymetrically shallow (Leckie, 1985; Hilbrecht et al., 1996; Čhech et al., 2005; Gräfe, 2005) or deep sites below the CCD (Kuhnt, 1992; Švábenická et al., 1997; Bąk, 2006).

In Romania, the Cenomanian/Turonian Boundary Event has never been documented in any detail, but some mention of the associated radiolarian-rich levels had been made by Neagu (1970) in the Upper Cenomanian of the Teleajen Nappe in the Eastern Carpathians. This paper presents preliminary biostratigraphical results from an Upper Albian *Correspondence: C.G. Cetean (ceteanc@yahoo.com) to Lower Turonian succession in the Stoeneşti - Cetățeni area (Dâmbovița Valley), which was deposited in a lower bathyal depositional setting.

The main purpose of this paper is to document the near extinction of benthic foraminiferal across the Cenomanian/Turonian boundary interval, and the initial stage of faunal recovery in the lowermost Turonian. In addition, this study brings new information about the stratigraphic range of some agglutinated species.

\section{GEOLOGICAL SETTING}

The present study concentrates on the lower part of the Upper Cretaceous succession that can be followed along the Dâmboviţa Valley between Stoeneşti and Cetățeni. The Upper Cretaceous deposits developed in the southern part of the East Carpathians in Dâmbovița Valley represent a part of the sedimentary cover of the Ceahlău Nappe, Outer Dacides (Săndulescu et al., 1981). The lower part of this stratigraphic succession in the Stoeneşti - Coteneşti area is represented by massive sandstones followed by finer deposits spanning from the Late Albian ("Vraconian") to Turonian with a short Middle - Late Cenomanian interval of flysch-type sedimentation (Murgeanu and Patrulius 1957; Murgeanu et al., 1963).

Above them, a sequence of Turonian - Santonian red marls and marly limestones with Inoceramus are present, followed by Campanian - Maastrichtian red marls with Belemnitella. The age of these sediments was confirmed based on ammonites and planktonic foraminifera by Murgeanu et al. (1963), Tocorjescu (1963), and Avram (1967). 


\section{MATERIAL AND METHODS}

Thirty-three samples from an outcrop in Coteneşti and 12 samples from a well drilled in Stoeneşti (given to the BBU Geology Department by Holcim S.A.) were investigated for their micropaleontological content (Fig. 1).

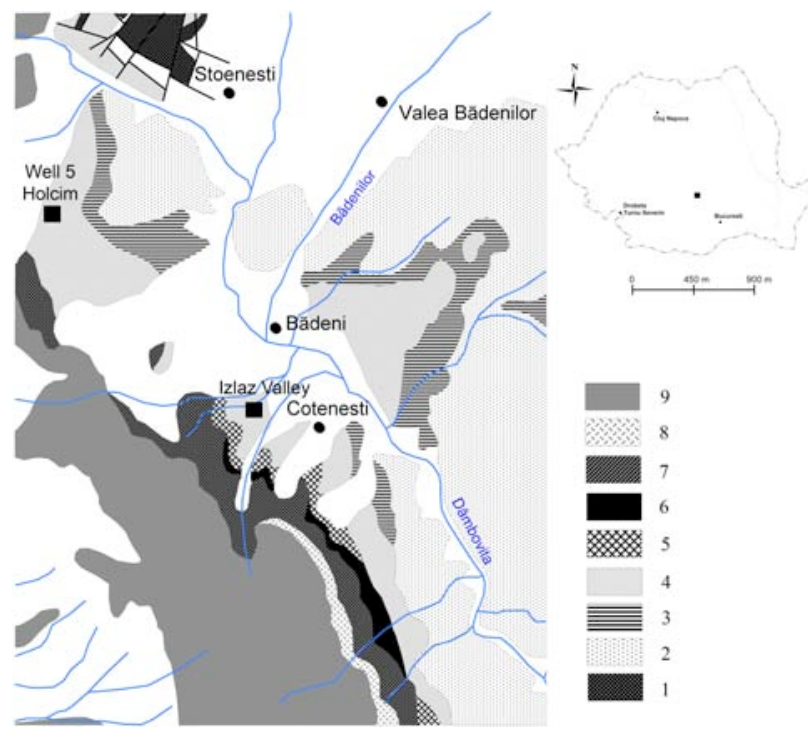

Fig. 1. Geological map of the Stoeneşti - Coteneşti area showing the position of the Well-5 Holcim, Stoenesti and the Izlaz Valley outcrop, Coteneşti.

1: Jurassic limestones; 2: Albian sandstones; 3: Upper Albian sandy marls; 4: Cenomanian - Turonian green and grey marls;

5: Santonian - Lower Campanian red marls and glauconitic sands/sandstones; 6: Upper Campanian-Lower Maastricthian red marls; 7-Maastrichtian red marls; 8: Upper MaastricthianYpresian red marls; 9: Eocene limestones and flysch deposits; 10: Pleistocene alluvial deposits; 11: Recent landslides (Modified after Geological Map of Romania, 1: 50.000, Sheet 128a, Câmpulung Muscel).

The outcrop from the Izlaz Valley consists of Upper Cenomanian green-grey marls and sandy marls with very thin interbedded sandstones in the lower part of the $15 \mathrm{~m}$ thick deposits. Thin laminated dark marls are also present (Fig. 2).

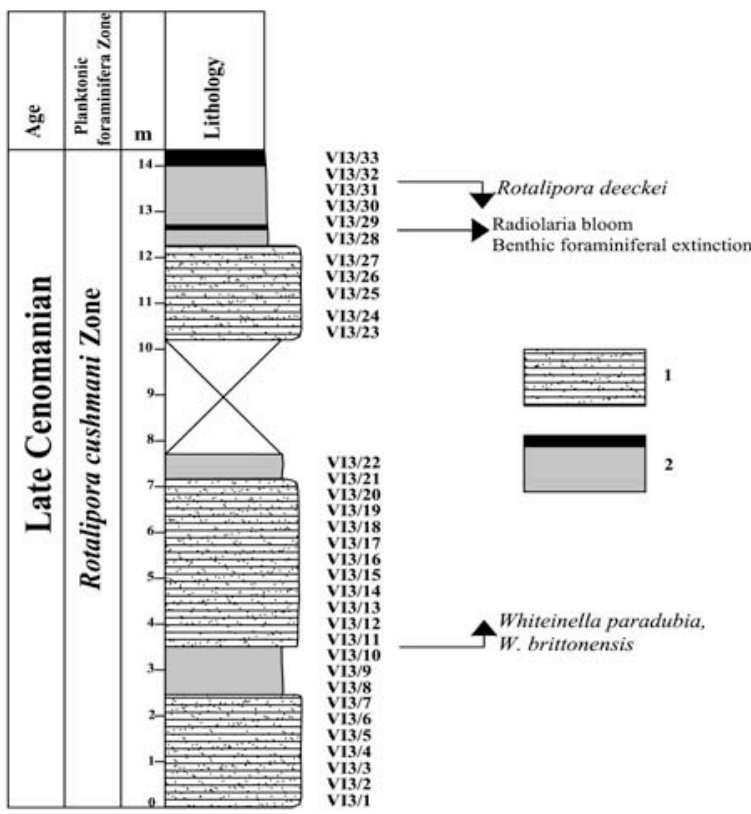

Fig. 2. Biostratigraphy of the Izlaz Valley section showing the position of the samples and main bioevents. Lithology: 1 - green sandy marls, 2 - grey to dark marls.
The well from Stoeneşti represents a complete succession of Late Albian to Early Turonian age starting with sandstones in the lower part, followed by a succession of grey marls and sandy marls characteristic of the Cenomanian. The Cenomanian/Turonian transition consists of black shales, while the lowermost Turonian is represented by alternating red and grey marls (Fig. 3). Based on the sedimentological features and the type of fauna we estimate for this Cenomanian - Turonian succession a lower slope paleodepth.

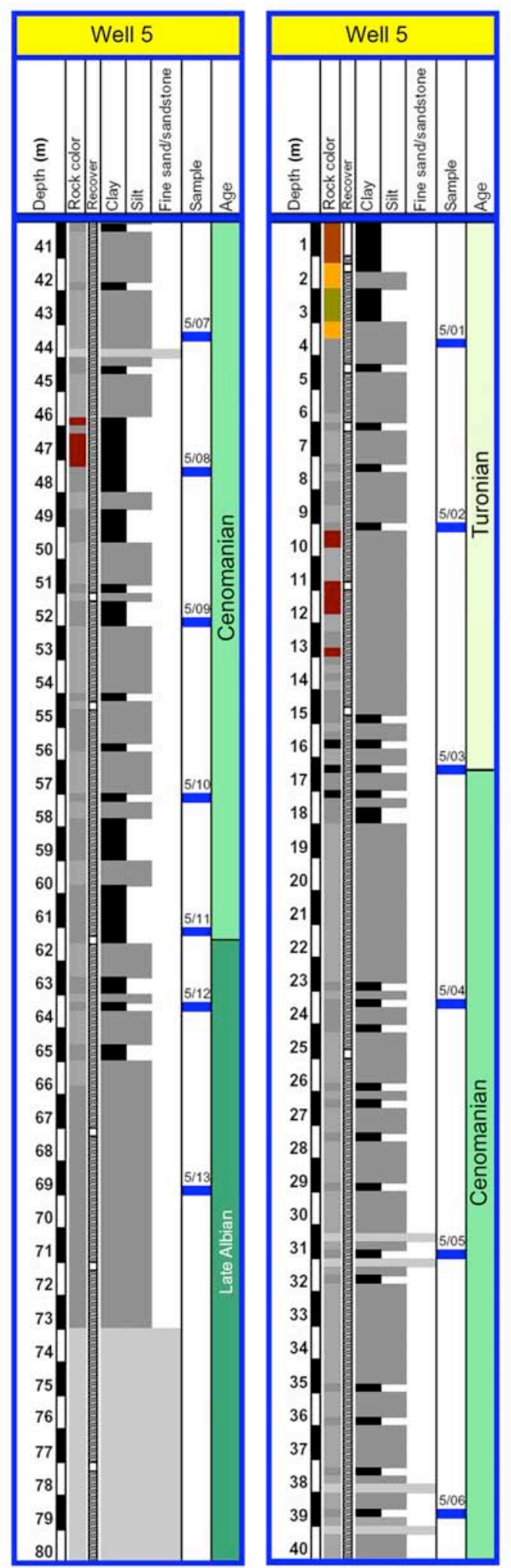

Fig. 3. Lithological column of Well-5 Holcim, showing the position of the samples and ages of the deposits based on planktonic foraminifera. 
For foraminifera, samples were boiled in water with sodium carbonate and washed over a $63 \mu \mathrm{m}$ sieve. Whenever possible, more than 300 individuals were picked. Preservation of foraminifera is good in the outcrop, but varies from very good to poor in the well. Planktonic foraminifera biostratigraphy is based on the Late Cretaceous scheme of Robaszynski and Caron (1995).

Individual specimens were photographed by using the scanning electron microscope in the Department of Biology of the Babeş-Bolyai University (BBU). Photographs of specimens in immersion oil were taken using a Olympus SZ61 microscope in the Geology Department of BBU.

Samples investigated for calcareous nannofossils (samples 5/1-5/3, Well-5, Holcim, Fig. 3) were prepared using the standard smear slide technique for light microscope (LM) observation.
The investigations were carried out under a light microscope (Nikon Optiphot 2 - Pol) at a magnification of 1000x using parallel and crossed nicols.

\section{RESULTS}

\subsection{Well-5 Holcim, Stoeneşti}

\subsubsection{Foraminifera}

The studied interval spans the Rotalipora appenninica Zone (Late Albian) to the upper part of the Whiteinella archaeocretacea Zone (Early Turonian). Probably owing to the poor preservation that occurs at some levels in the well, we were unable to identify the Rotalipora reicheli biozone in our samples. Planktonic foraminiferal biozones and the stratigraphic distribution of calcareous and agglutinated benthic foraminifera are shown in Table 1 and Table 2.

Table 1. Distribution of agglutinated foraminifera in Well-5 Holcim, Stoeneşti.

\begin{tabular}{|c|c|c|c|c|c|c|c|c|c|c|c|c|}
\hline \multirow{3}{*}{$\begin{array}{r}\text { Agglutinated Foraminifera } \\
\text { Sample no. }\end{array}$} & \multirow{3}{*}{$\begin{array}{c}\text { Late Albian } \\
\begin{array}{c}\text { R. apenninica } \\
\text { Zone }\end{array} \\
\mathbf{5 / 1 2}\end{array}$} & \multicolumn{3}{|c|}{ Early Cenomanian } & \multicolumn{5}{|c|}{ Middle - Late Cenomanian } & \multicolumn{3}{|c|}{ Early Turonian } \\
\hline & & \multicolumn{3}{|c|}{ R. globotruncanoides Zone } & \multicolumn{2}{|c|}{$\begin{array}{l}\text { ?R. reicheli } \\
\text { Zone }\end{array}$} & \multicolumn{3}{|c|}{$\begin{array}{l}\text { R. cushmani } \\
\text { Zone }\end{array}$} & \multicolumn{3}{|c|}{$\begin{array}{c}\text { W. archaeocretacea } \\
\text { Zone }\end{array}$} \\
\hline & & $5 / 11$ & $5 / 10$ & $5 / 9$ & $5 / 8$ & $5 / 7$ & $5 / 6$ & $5 / 5$ & $5 / 4$ & $5 / 3$ & $5 / 2$ & $5 / 1$ \\
\hline Ammodiscus cretaceus & $\mathrm{x}$ & $\mathrm{x}$ & $\mathrm{x}$ & $\mathrm{x}$ & & & & & $\mathrm{x}$ & & & \\
\hline Ammodiscus planus & $\mathrm{x}$ & $\mathrm{x}$ & & $\mathrm{x}$ & $\mathrm{x}$ & & & & $\mathrm{x}$ & & & \\
\hline Ammodiscus infimus & & & & $\mathrm{x}$ & & $\mathrm{x}$ & $\mathrm{x}$ & & & & & \\
\hline Arenobulimina presli & & & & & & $\mathrm{x}$ & & & $\mathrm{x}$ & & & \\
\hline Bathysiphon sp. & & & & $\mathrm{x}$ & & & $\mathrm{x}$ & & $\mathrm{x}$ & & & \\
\hline Bulbobaculites problematicus & $\mathrm{x}$ & $\mathrm{x}$ & $\mathrm{x}$ & $\mathrm{x}$ & $\mathrm{x}$ & $\mathrm{x}$ & $\mathrm{x}$ & $\mathrm{x}$ & $\mathrm{x}$ & & $\mathrm{x}$ & \\
\hline Bulbobaculites lueckei & & & & & & $\mathrm{x}$ & $\mathrm{x}$ & & & & & \\
\hline Dorothia conulus & & & & $\mathrm{x}$ & & & $\mathrm{x}$ & & $\mathrm{x}$ & & & \\
\hline Dorothia pupa & & $\mathrm{x}$ & & $\mathrm{x}$ & & & $\mathrm{x}$ & & $\mathrm{x}$ & & & \\
\hline Falsogaudrynella moesiana & $\mathrm{x}$ & & $\mathrm{x}$ & $\mathrm{x}$ & & & & & & & & \\
\hline Gaudryna carinata & $\mathrm{x}$ & $\mathrm{x}$ & $\mathrm{x}$ & & & & $\mathrm{x}$ & & $\mathrm{x}$ & & & \\
\hline Gaudryna sp. & $\mathrm{x}$ & & $\mathrm{x}$ & $\mathrm{x}$ & & & $\mathrm{x}$ & & $\mathrm{x}$ & & & \\
\hline Gerochammina stanislawi & $\mathrm{x}$ & & & $\mathrm{x}$ & & & $\mathrm{x}$ & & $\mathrm{x}$ & & $\mathrm{x}$ & \\
\hline Glomospira charoides & & & & $\mathrm{x}$ & & $\mathrm{x}$ & & & & & $\mathrm{x}$ & \\
\hline Glomospira gordialis & & & $\mathrm{x}$ & $\mathrm{x}$ & & $\mathrm{x}$ & $\mathrm{x}$ & & & & & \\
\hline Haplophragmoides sp. & & & & & & & & & & $\stackrel{1}{=}$ & $\mathrm{x}$ & \\
\hline Haplophragmoides & & & & & & & & & & $\bar{\Xi}$ & & \\
\hline falcatosuturalis & & $\mathrm{X}$ & $\mathrm{X}$ & $\mathrm{X}$ & & $\mathrm{X}$ & & & $\mathrm{X}$ & ह. & & \\
\hline Haplophragmoides kirki & $\mathrm{x}$ & $\mathrm{x}$ & $\mathrm{x}$ & $\mathrm{x}$ & & $\mathrm{x}$ & & & $\mathrm{x}$ & E. & & \\
\hline Haplophragmoides nonioides & $\mathrm{x}$ & $\mathrm{x}$ & & $\mathrm{x}$ & & $\mathrm{x}$ & $\mathrm{x}$ & & $\mathrm{x}$ & $\stackrel{\overline{0}}{0}$ & & \\
\hline Haplophragmoides sp.1 & $\mathrm{x}$ & & $\mathrm{x}$ & $\mathrm{x}$ & & & $\mathrm{x}$ & & $\mathrm{x}$ & $\sum^{2}$ & & \\
\hline Hormosina velascoensis & & & & $\mathrm{x}$ & & & & & & $\stackrel{2}{0}$ & & \\
\hline Kalamopsis grzybowskii & $\mathrm{x}$ & $\mathrm{x}$ & $\mathrm{x}$ & $\mathrm{x}$ & & $\mathrm{x}$ & $\mathrm{x}$ & & $\mathrm{x}$ & & & \\
\hline Hyperammina gaultina & & & & & & & $\mathrm{x}$ & & & & & \\
\hline Nothia sp. & $\mathrm{x}$ & $\mathrm{x}$ & $\mathrm{x}$ & $\mathrm{x}$ & $\mathrm{x}$ & $\mathrm{x}$ & $\mathrm{x}$ & $\mathrm{x}$ & $\mathrm{x}$ & & & \\
\hline Plectorecurvoides irregularis & $\mathrm{x}$ & & & & & & & & & & & \\
\hline Pokornyammina clara & & $\mathrm{x}$ & $\mathrm{x}$ & & & $\mathrm{x}$ & & & $\mathrm{x}$ & & & \\
\hline Praedorothia gradata & $\mathrm{x}$ & & & $\mathrm{x}$ & & $\mathrm{x}$ & $\mathrm{x}$ & & & & & \\
\hline Protomarssonella sp. & & $\mathrm{x}$ & $\mathrm{x}$ & $\mathrm{x}$ & & & $\mathrm{x}$ & & $\mathrm{x}$ & & & \\
\hline Pseudobolivina sp.2 & $\mathrm{x}$ & $\mathrm{x}$ & & $\mathrm{x}$ & & $\mathrm{x}$ & $\mathrm{x}$ & & & & $\mathrm{x}$ & $\mathrm{x}$ \\
\hline Recurvoides sp. & $\mathrm{x}$ & $\mathrm{x}$ & $\mathrm{x}$ & $\mathrm{x}$ & & & $\mathrm{x}$ & $\mathrm{x}$ & $\mathrm{x}$ & & & \\
\hline Reophax parvulus & $\mathrm{x}$ & $\mathrm{x}$ & $\mathrm{x}$ & & & $\mathrm{x}$ & $\mathrm{x}$ & & $\mathrm{x}$ & & $\mathrm{x}$ & \\
\hline Rhizammina sp. & $\mathrm{x}$ & $\mathrm{x}$ & $\mathrm{x}$ & $\mathrm{x}$ & $\mathrm{x}$ & & $\mathrm{x}$ & $\mathrm{x}$ & $\mathrm{x}$ & & $\mathrm{x}$ & \\
\hline Scherochorella minuta & $\mathrm{x}$ & $\mathrm{x}$ & $\mathrm{x}$ & $\mathrm{x}$ & & $\mathrm{x}$ & $\mathrm{x}$ & & & & & \\
\hline Spiroplectammina roemeri & & & & & & & $\mathrm{x}$ & & $\mathrm{x}$ & & & \\
\hline Tritaxia gaultina carinata & $\mathrm{x}$ & $\mathrm{x}$ & $\mathrm{x}$ & $\mathrm{x}$ & $\mathrm{x}$ & $\mathrm{x}$ & $\mathrm{x}$ & & $\mathrm{x}$ & & & \\
\hline
\end{tabular}

Benthic foraminiferal assemblages are well diversified, and include both calcareous and agglutinated taxa. However, in the whole succession a high number of agglutinated genera were identified and calcareous benthics represent only a minor component (25-10\%) of the assemblages for the Cenomanian, and are absent in the lowermost Turonian.

Long-ranging genera of agglutinated foraminifera in the Upper Albian - Lower Turonian succession include deep infaunal forms such as Bulbobaculites problematicus, Gerochammina stanislawi, Reophax parvulus and tubular forms such as Nothia sp., Rhizammina sp. and Kalamopsis grzybowskii. These genera represent the dominant component of the microfauna in Cenomanian, together with other long ranging forms such as Tritaxia gaultina carinata, Haplophragmoides nonioninoides, H. kirki, Dorothia pupa and Protomarssonella sp.

The presence of Pokornyammina clara spans the whole Cenomanian in the studied interval. This genus established by Neagu and Platon, 1994 (previously described as Thalmannammina recurvoidiformis Neagu and Tocorjescu, 1970), has been reported before in other micropaleontological studies in different nappes of the Eastern Studia UBB, Geologia, 2008, 53 (1), $11-23$ 
Carpathians as having its first occurrence (FO) in the Late had been mentioned by Neagu et al. (1992).

Albian (Ion, 1975a,b). Its presence in the Early Cenomanian

Table 2. Distribution of calcareous foraminifera (benthics and planktonics) and calcareous nannofossils in Well-5 Holcim, Stoeneşti.

\begin{tabular}{|c|c|c|c|c|c|c|c|c|c|c|c|c|c|}
\hline \multirow{3}{*}{\multicolumn{2}{|c|}{$\begin{array}{l}\text { Calcareous Foraminifera } \\
\text { \& } \\
\text { Calcareous nannofossils } \\
\\
\text { Sample no. }\end{array}$}} & \multirow{3}{*}{$\frac{c \text { Late Albian }}{\text { R. apenninica Zone }}$} & \multirow{2}{*}{\multicolumn{3}{|c|}{$\frac{\text { Early Cenomanian }}{\text { R. brotzeni Zone }}$}} & \multicolumn{5}{|c|}{ Middle - Late Cenomanian } & \multirow{2}{*}{\multicolumn{3}{|c|}{$\begin{array}{c}\text { Early Turonian } \\
\begin{array}{l}\text { W. archaeocretacea } \\
\text { Zone }\end{array}\end{array}$}} \\
\hline & & & & & & \multicolumn{2}{|c|}{ ?R. reicheli Zone } & \multicolumn{3}{|c|}{ R. cushmani Zone } & & & \\
\hline & & & $5 / 11$ & $5 / 10$ & $5 / 9$ & $5 / 8$ & $5 / 7$ & $5 / 6$ & $5 / 5$ & $5 / 4$ & $5 / 3$ & $5 / 2$ & $5 / 1$ \\
\hline \multirow{15}{*}{ 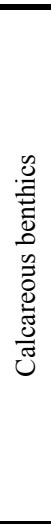 } & Astacolus crepidulus & & & $\mathrm{x}$ & $\mathrm{x}$ & & & & & & & & \\
\hline & Berthelina cenomana & & & & $\mathrm{x}$ & & & $\mathrm{x}$ & & $\mathrm{x}$ & & & \\
\hline & Dentalina legumen & & & $\mathrm{x}$ & $\mathrm{x}$ & & & $\mathrm{x}$ & & $\mathrm{x}$ & & & \\
\hline & Dentalina sp. & $\mathrm{x}$ & & $\mathrm{x}$ & $\mathrm{x}$ & $\mathrm{x}$ & $\mathrm{x}$ & $\mathrm{x}$ & $\mathrm{x}$ & $\mathrm{x}$ & & & \\
\hline & Frondicularia $s p$. & & & $\mathrm{x}$ & & & & & & & & & \\
\hline & $\begin{array}{l}\text { Gavelinella } \\
\text { schloenbachii }\end{array}$ & & & & $\mathrm{x}$ & & $\mathrm{x}$ & $\mathrm{x}$ & & $\mathrm{x}$ & & & \\
\hline & Globorotalites brotzeni & & $\mathrm{x}$ & $\mathrm{x}$ & $\mathrm{x}$ & & & $\mathrm{x}$ & & & & & \\
\hline & Gyroidinoides nitidus & & & $\mathrm{x}$ & $\mathrm{x}$ & & & $\mathrm{x}$ & & $\mathrm{x}$ & & & \\
\hline & Laevidentalina $s p$ & & & $\mathrm{x}$ & $\mathrm{x}$ & $\mathrm{x}$ & & & $\mathrm{x}$ & $\mathrm{x}$ & & & \\
\hline & Lagena apiculata & $\mathrm{x}$ & $\mathrm{x}$ & $\mathrm{x}$ & & & & & & $\mathrm{x}$ & & & \\
\hline & Lenticulina sp. & $\mathrm{x}$ & $\mathrm{x}$ & & $\mathrm{x}$ & & & $\mathrm{x}$ & & $\mathrm{x}$ & & & \\
\hline & Nodosaria lepida & $\mathrm{x}$ & $\mathrm{x}$ & $\mathrm{x}$ & $\mathrm{x}$ & & & $\mathrm{x}$ & & $\mathrm{x}$ & & & \\
\hline & Nodosaria sp. & $\mathrm{x}$ & $\mathrm{x}$ & $\mathrm{x}$ & $\mathrm{x}$ & & & $\mathrm{x}$ & & $\mathrm{x}$ & & & \\
\hline & Pleurostomella reussi & & & & $\mathrm{x}$ & & & $\mathrm{x}$ & & & & & \\
\hline & Ramulina novaculeata & $\mathrm{x}$ & & $\mathrm{x}$ & & & $\mathrm{x}$ & $\mathrm{x}$ & & & & & \\
\hline \multirow{13}{*}{ 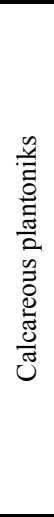 } & $\begin{array}{l}\text { Dicarinella cf. } \\
\text { algeriana }\end{array}$ & & & & & & & & & & & $\mathrm{x}$ & \\
\hline & Hedbergella delrioensis & $\mathrm{x}$ & $\mathrm{x}$ & $\mathrm{x}$ & $\mathrm{x}$ & & & $\mathrm{x}$ & & $\mathrm{x}$ & & & \\
\hline & Hedbergella planispira & $\mathrm{x}$ & $\mathrm{x}$ & $\mathrm{x}$ & $\mathrm{x}$ & & & $\mathrm{x}$ & & $\mathrm{x}$ & & & \\
\hline & $\begin{array}{l}\text { Praeglobotruncana } \\
\text { gibba }\end{array}$ & & & & & & & & & $\mathrm{x}$ & & & \\
\hline & $\begin{array}{l}\text { gibba } \\
\text { Rotalipora appenninica }\end{array}$ & $\mathrm{x}$ & $\mathrm{x}$ & $\mathrm{x}$ & $\mathrm{x}$ & & $\mathrm{x}$ & & & & $\pi$ & & \\
\hline & Rotalipora brotzeni & & $\mathrm{x}$ & $\mathrm{x}$ & $\mathrm{x}$ & & & $\mathrm{x}$ & & & & & \\
\hline & Rotalipora cushmani & & 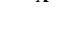 & 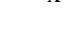 & & & & $\mathrm{x}$ & & $\mathrm{x}$ & E. & & \\
\hline & Rotalipora deeckei & & & & & & & & & $\mathrm{x}$ & 它. & & \\
\hline & Rotalipora gandolfii & $\mathrm{x}$ & $\mathrm{x}$ & $\mathrm{x}$ & $\mathrm{x}$ & & & & & & . & & \\
\hline & Rotalipora micheli & & & $\mathrm{x}$ & $\mathrm{x}$ & & & $\mathrm{x}$ & & & $\underline{\underline{a}}$ & & \\
\hline & Rotalipora & & & & & & & $\mathrm{x}$ & & $\mathrm{x}$ & 该 & & \\
\hline & $\begin{array}{l}\text { montsalvensis } \\
\text { Whiteinella brittonensis }\end{array}$ & & & & & & & & & $x$ & & & \\
\hline & Whiteinella sp. & & & & & & & & & & & $\mathrm{x}$ & \\
\hline \multirow{16}{*}{ 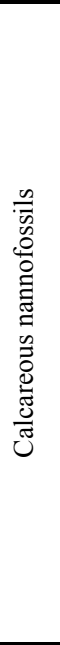 } & $\begin{array}{l}\text { Axopodorhabdus } \\
\text { albianus }\end{array}$ & & & & & & & & & & & $\mathrm{x}$ & $\mathrm{x}$ \\
\hline & Biscutum constans & & & & & & & & & & & $\mathrm{x}$ & $\mathrm{x}$ \\
\hline & Cylindralithus biarcus & & & & & & & & & & & $\mathrm{x}$ & $\mathrm{x}$ \\
\hline & Eiffelithus turriseiffelii & & & & & & & & & & & $\mathrm{x}$ & $\mathrm{x}$ \\
\hline & Eprolithus floralis & & & & & & & & & & & $\mathrm{x}$ & $\mathrm{x}$ \\
\hline & Eprolithus octopetalus & & & & & & & & & & & $\mathrm{x}$ & $\mathrm{x}$ \\
\hline & Gartnerago & & & & & & & & & & & & $\mathrm{x}$ \\
\hline & segmentatum & & & & & & & & & & & $\mathrm{x}$ & \\
\hline & $\begin{array}{l}\text { Manivitella } \\
\text { pemmatoidea }\end{array}$ & & & & & & & & & & & $\mathrm{x}$ & $\mathrm{x}$ \\
\hline & $\begin{array}{l}\text { pemmatoldea } \\
\text { Microrhabdulus }\end{array}$ & & & & & & & & & & & & \\
\hline & decoratus & & & & & & & & & & & & $\mathrm{x}$ \\
\hline & $\begin{array}{l}\text { Prediscosphaera } \\
\text { columnata }\end{array}$ & & & & & & & & & & & $\mathrm{x}$ & $\mathrm{x}$ \\
\hline & Quadrum gartneri & & & & & & & & & & & & $\mathrm{x}$ \\
\hline & Quadrum intermedium & & & & & & & & & & & $\mathrm{x}$ & $\mathrm{x}$ \\
\hline & Rhagodiscus & & & & & & & & & & & $\mathrm{x}$ & $\mathrm{x}$ \\
\hline & Watznaueria barnesiae & & & & & & & & & & & $\mathrm{x}$ & $\mathrm{x}$ \\
\hline
\end{tabular}

The two biozones established by Neagu et al. (1992) for the Eastern Carpathians based on agglutinated foraminifera are: the Haplophragmoides falcatosuturalis Zone for the Late Albian (Vraconian) - Early Cenomanian interval and the Bulbobaculites problematicus Zone for the Middle Cenomanian to Late Turonian interval. In our samples, Haplophragmoides falcatosuturalis has a larger stratigraphical range, extending to the end-Cenomanian anoxic event. Therefore, the two biozones as documented by Neagu et al. (1992), could not be separated in the studied deposits.

Three last occurrences LO's of agglutinated species were observed in the investigated stratigraphic interval. Studia UBB, Geologia, 2008, 53 (1), 11 - 23
Plectorecurvoides irregularis has its LO in the upper part of the Rotalipora appenninica Zone (Late Albian), Falsogaudrynella moesiana disappears in the upper part of the $R$. globotruncanoides Zone, Scherochorella minuta has its LO in the lower part of the R. cushmani Zone (upper part of the Middle Cenomanian). The stratigraphic range of Falsogaudrynella moesiana documented by Kaminski et al. (1995) is Albian; in our succession this species extends to the top of the Lower Cenomanian.

The Cenomanian/Turonian boundary (corresponding to sample $5 / 3$ in Fig. 3) is is placed within black shales that are barren of foraminifera. 
The first Early Turonian foraminiferal assemblage consists entirely of agglutinated taxa: Haplophragmoides sp., Glomospira charoides, Bulbobaculites problematicus, Gerochammina stanislawi, Rhizammina sp., Reophax parvulus and Pseudobolivina sp. 2 (sensu Kuhnt, 1992).

The low diversity of agglutinated foraminifera (Fig. 4), having small dimensions and thin walls, are similar to the reported recolonization faunas after the Cenomanian/ Turonian boundary anoxic level from different land sections and ODP sites (Kuhnt, 1992; Coccioni et al., 1995 among others).

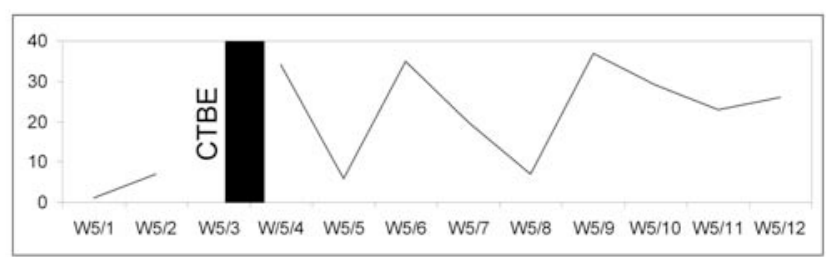

Fig. 4. Number of species per sample in Well-5 Holcim, Stoeneşti.

Early Turonian planktonic foraminifera in Well-5 Holcim, Stoeneşti are very rare, only two specimens of Whiteinella sp. were found in the first investigated sample after the boundary. Grey to dark marls at the top of the deposits in the well suggest that low oxygen conditions may had occured again in the Early Turonian, as only one agglutinated species Pseudobolivina sp. 2 (sensu Kuhnt, 1992) can be found together with the planktonic foraminifera Dicarinella cf. algeriana in the studied interval.

\subsubsection{Calcareous nannofossils}

In order to confirm the Early Turonian age of the upper part of the well succesion, three samples were investigated for calcareous nannofossils. The black clay level (corresponding to sample 5/3 in Fig. 3) which was found to be barren of foraminifera, is also lacking calcareous nannofossils.

Above this level, calcareous nannofossils assemblage consists of new species: Quadrum intermedium, Eprolithus octopetalus, Quadrum gartneri and Microrhabdulus decoratus, together with long-ranging taxa as: Eiffelithus turriseiffellii, Eprolithus floralis, Cretarhabdus conicus, Watznaueria barnesiae. The presence of these new species confirms an Early Turonian age.

\subsection{Izlaz Valley, Coteneşti}

Rotalipora cushmani is present in the whole studied succession from the Izlaz Valley outcrop. Two main bioevents were identified: the FOs of Whiteinella paradubia and $W$. brittonensis at $3.5 \mathrm{~m}$ from the base of the outcrop and the LO of $R$. deeckei at 13.7 from the base of the outcrop.

These changes in the composition of planktonic foraminiferal assemblages allowed us to determine the investigated interval as representing the middle to upper part of the Rotalipora cushmani Zone.

Benthic foraminifera from the Izlaz Valley are very similar to the Late Cenomanian fauna recorded in Well-5, Stoeneşti. However, Scherochorella minuta is missing in the outcrop samples. This might confirm a late Cenomanian age, as this agglutinated species disappears in the lower part of the R. cushmani Zone (late Middle Cenomanian) in the Well-5 Holcim.
At $12.6 \mathrm{~m}$ from the base on the outcrop, a thin dark shales interval is observed. Benthic foraminifera are absent in this interval, instead a high number of spherical recrystalized and pyritized radiolarians are present. Also, high numbers of radiolarians are observed at others levels in the outcrop (between $7-8 \mathrm{~m}$ from the base of the outcrop) together with impoverished benthic foraminiferal assemblages.

\section{DISCUSSION}

Radiolarian-rich black shales are recorded in the Carpathian basin and in other Tethyan areas around the Cenomanian/Turonian boundary (Luciani and Cobianchi, 1999; Scopelliti et al., 2004; Bąk, 2006 among others). These short-lived radiolarian-rich levels are thought to represent episodes of coastal upwelling in the SubsilesianSilesian basin in Poland (Bak, 2006). High numbers of radiolarians in the Gubbio "Bonarelli Level" are considered to be indicators of highly eutrophic conditions that resulted in the expansion of the oxygen minimum zone (Coccioni and Luciani, 2004).

We encountered a level of radiolarian-rich dark shales within the upper part of Rotalipora cushmani Zone in the Izlaz Valley, Coteneşti. In this level benthic foraminifera are absent, planktonic foraminifera are scarce and represented by large forms of Rotalipora sp. and few specimens of Whiteinella sp. This may indicate that low oxygen conditions occured since Late Cenomanian in this part of the Carpathian basin as recorded by high-resolution sampling of this interval.

Changes in the foraminiferal assemblages during the Late Cenomanian as indicators of temporary low oxygen levels were observed in several land sections in Europe and Japan. Low diversity foraminiferal assemblages suggesting an interval with dysoxic conditions at the sea floor were reported in the Gubbio section of Umbria-Marche, Italy in the middle of the Rotalipora cushmani Zone (Coccioni and Luciani, 2004). A benthic foraminiferal extinction was also found in the Upper Cenomanian of the Hokkaido area, Japan, preceding the black shale interval corresponding to the "Bonarelli Level" where a second benthic-free level was recorded (Kaiho, 1994). In the Menoyo section, Spain, a major faunal turnover was observed in the upper Cenomanian at the top of the Rotalipora cushmani Zone, consisting of a stepwise disappearance of 33 species of benthic foraminifera, some of which return when the oxygenation levels are restored (Peryt, 2004).

The Cenomanian/Turonian boundary interval is barren of foraminifera in most of the studied sites from the North Atlantic and Europe (Kuhnt, 1992; Coccioni and Luciani, 2004; Scopelliti et al., 2004; Bak, 2006 among others), but in the Ganuza section, Spain and the deepest sites of Demerara Rise, ODP Leg 207, a benthic extinction is not evident, only low diversity and poor assemblages occur as result of low oxygen levels represented by this interval (Peryt, 2004; Friedrich et al., 2006).

The Cenomanian/Turonian boundary interval from Well-5, Holcim is represented by a level of black shales barren of foraminifera and calcareous nannofossils.

FO of Quadrum intermedium can be observed in Well-5, Holcim, sample 5/2, below the FO of Quadrum gartneri. Burnett (1998) and Čech et al. (2005) reported this event in Late Cenomanian, using this species to define UC5c subzone. Paul et al. (1999) reported the FO of Quadrum 
intermedium above the FO of Quadrum gartneri in the Early Turonian. Varol (1992) mentioned the presence of this species in a short interval between Early and Middle Turonian.

This bioevent (FO of Quadrum intermedium) in the Well-5 Holcim succession is synchronous with the FO of Eprolithus octopetalus. This species has a short range in the Late Cenomanian-Early Turonian (Varol, 1992). Gorostidi and Lamolda (1993) had reported it only in the upper part of Late Cenomanian. Burnett (1998) identified it only in Early Turonian below the FO of Quadrum gartneri, at the base of UC6b subzone. Luciani and Cobianchi (1999) reports the FO of Eprolithus octopetalus in CC11 Zone, in the lower part of Helvetoglobotruncana helvetica Zone.

The FO of Quadrum gartneri is used as an indicator for the Cenomanian/Turonian boundary. Burnett (1998) placed this event in the upper part of the Early Turonian (UC7 Zone). Kennedy et al. (2000) and Tsikos et al. (2004) used this event to establish both the Cenomanian/Turonian boundary and the end of the anoxic event (OAE2). In the investigated samples from Well-5 Holcim, this species is present together with Axopodorhabdus albianus, as it was reported by Hardas and Mutterlose (2006) at Demerara Rise (ODP Leg 207). Bralower (1988) described the FO of Quadrum gartneri below the LO of Axopodorhabdus albianus. Most studies report the FO of Quadrum gartneri above LO of Axopodorhabdus albianus (Lamolda et al., 1997; Burnett, 1998; Nederbragt and Fiorentino, 1999; Luciani and Cobianchi, 1999; Paul et al., 1999; Tsikos et al., 2004).

The first step of faunal recolonization in our samples above the benthic-free interval corresponding to the boundary event is represented by small, thin-walled agglutinated foraminifera. In the lowermost Turonian, six species return as "Lazarus taxa": Glomospira charoides, Bulbobaculites problematicus, Gerochammina stanislawi, Rhizammina sp., Reophax parvulus and Pseudobolivina sp. 2 (sensu Kuhnt, 1992). However, Glomospira charoides and a species of Haplophragmoides constitute $70 \%$ of the agglutinated foraminiferal assemblage; a characteristic of stressed environments that have low diversity and a high dominance of few taxa (Jorissen et al., 1995). This type of agglutinated assemblage, described as "Biofacies B" by Kuhnt and Kaminski (1989) are known from oxygendepleted Cretaceous to Paleogene environments and consist mostly of opportunistic taxa such as Glomospira sp., Ammodiscus and thin tubular form Rhizammina sp. Additional species may be present in the Lower Turonian recovery interval, such as Pseudobolivina sp. 2 and diverse species of Haplophragmoides: $H$. concavus, $H$. cf. pseudokirki from the deep-water limestone Scaglia succession at Gubbio, and North Atlantic ODP Site 641A (Kuhnt 1990, 1992; Coccioni et al. 1995). The recovery fauna from the lowermost Turonian of Well-5 Holcim is very similar to the correlative fauna from North Atlantic ODP Site 641A documented by Kuhnt (1992).

\section{CONCLUSIONS}

The upper Albian to Lower Turonian succession from Well-5, Stoeneşti and the Izlaz Valley outcrop at Coteneşti prove that this area of the Eastern Carpathians represents an excellent lower bathyal setting for studying the Cenomanian/Turonian boundary event as foraminifera can be correlated with other groups of microfossils (calcareous nannofossils, radiolaria). We document for the first time the benthic-free interval corresponding to the "Bonarelli Level" in the Romanian Carpathians and the faunal changes associated with it. A radiolarian-rich level devoid of benthic foraminifera, is encountered in the studied sections from the upper Cenomanian Rotalipora cushmani Zone, showing that the deterioration of paleoenvironmental conditions began earlier in this part of the Carpathian basin. After the Cenomanian/Turonian boundary event, in the Lower Turonian, the first stage of the recolonization after the anoxic interval consists of small, thin walled agglutinated genera similar to those reported from other deep-water settings.

Further studies in this area will bring new information about the detailed response of the benthic foraminifera to CTBE in the Romanian Carpathians, in order to develop a more generalized model of foraminiferal extinction, recovery, and faunal succession that accompanied this event.

Acknowledgements. CGC wishes to thanks Alexandru Hosu (Holcim S.A.) for providing the well material and Isabella Premoli Silva for the help with the planktonic foraminifera identifications. The authors would also like to thank the reviewers: T. Neagu (Laboratory of Paleontology, University of Bucharest) and M. Lamolda (University of Granada) for their useful suggestions.

\section{R E F E R E N C E S}

Arthur, M.A., Premoli-Silva, I. 1982, Development of widespread organic carbon-rich strata in Mediterranean Tethys. In: Nature and Origin of Cretaceous Carbonrich Facies (Schlanger, S.O. \& Cita, M.B., Eds.). Academic Press, London, p. 7-54.

Avram E. 1967, Consideraţii paleontologice asupra Cretacicului Superior de la Stoeneşti - Coteneşti (V. Dâmboviței). Studii şi cercetări de Geologie, Geofizică, Geografie, Seria Geologie, 12 (1): 237-242.

Bąk, K. 2006, Sedimentological, geochemical and microfaunal responses to environmental changes around the Cenomanian-Turonian boundary in the Outer Carpathian Basin; a record from the Subsilesian Nappe, Poland. Palaeogeography, Palaeoclimatology, Palaeoecology, 237: 335-358.

Bralower, T.J. 1988, Calcareous nannofossil biostratigraphy and assemblages of the Cenomanian-Turonian boundary interval: implications for the origin and timing of oceanic anoxia. Paleoceanography, 3: 275-316.

Burnett, J.A. 1998, Upper Cretaceous. In: Calcareous Nannofossil Biostratigraphy (Bown, P.R., Ed.). Chapman and Hall, London, p. 132-199.

Coccioni, R., Galeotti, S. \& Gravili, M. 1995, Latest AlbianEarliest Turonian deep-water agglutinated foraminifera in the Bottaccione section (Gubbio, Italy) biostratigraphic and paleoecologic implications. Revista Española de Paleontologia, No. Homenaje al Dr. Guillermo Colom: 135-152.

Coccioni, R., Luciani V. 2004, Planktonic foraminifera and environmental changes across the Bonarelli Event (OAE2, Latest Cenomanian) in its type area: A highresolution study from the tethyan reference Bottaccione section (Gubbio, central Italy). Journal of Foraminiferal Research, 34 (2): 109-129. 
Čech, S., Hradecká, L., Svobodová, M. \& Švábenická, L. 2005, Cenomanian and Cenomanian-Turonian boundary in the southern part of the Bohemian Cretaceous Basin, Czech Republic. Bulletin of Geosciences, 80 (4): 321-354.

Ernst, G., Wood, C.J. \& Hilbrecht, H. 1984, The Cenomanian-Turonian boundary problem in NWGermany with comments on the north-south correlation to the Regensburg area. Bulletin of the Geological Society of Denmark, 33: 103-113.

Friedrich, O., Erbacher, J. \& Mutterlose, J. 2006, Paleoenvironmental changes across the Cenomanian/ Turonian Boundary Event (Oceanic Anoxic Event 2) as indicated by benthic foraminifera from the Demerara Rise (ODP Leg 207). Revue de Micropaléontologie, 49: 121-139.

Gräfe, K.-U. 2005, Late Cretaceous benthic foraminifers from Basque-Cantabrian Basin, Northern Spain. Iberian Geology, 31: 277-298.

Gorostidi, A., Lamolda, M.A. 1993, Field-guide excursion to the Maastrichtian-Danian, Zumaya Section, and to the Cenomanian-Turonian, Menoyo Section (Northern Spain). Excursion Guide of the $5^{\text {th }}$ INA Conference: p. 1-18, Salamanca.

Hardas, P., Mutterlose, J. 2006, Calcareous nannofossil biostratigraphy of the Cenomanian/Turonian boundary interval od ODP Leg 207 at the Demerara Rise. Revue de micropaléontologie, 49: 165-179.

Hilbrecht, H., Frieg, C., Tröger, K.-A., Voigt, S. \& Voigt, T. 1996, Shallow water facies during the CenomanianTuronian anoxic event: bio-events, isotopes, and sea level in southern Germany. Cretaceous Research, 17: 229-253.

Ion J. 1975a, Microbiostratigraphie, associations et zones a foraminifères du Crétacé du flysch externe des Carpates Orientales (Roumanie). Revista Española de Micropaleontologia, 7 (1): 99-111.

Ion J. 1975b, Zone de foraminifères dans l'Albien Senonien des Carpates Orientales. Dări de seamă ale Institutului de Geologie şi Geofizică, 62 (4): 93-120.

Jorissen, F. J., Stigter, H.C. \& Widmark, J.G.V. 1995, A conceptual model explaining benthic foraminiferal microhabitats. Marine Micropaleontology, 26: 3-15.

Kaiho, K., Hasegawa, T. 1994, End-Cenomanian benthic foraminiferal extinctions and oceanic dysoxic events in the northwestern Pacific Ocean. Palaeogeography, Palaeoclimatology, Palaeoecology, 111: 29-43.

Kaminski M. A., Neagu, T. \& Platon E. 1995, A revision of the Lower Cretaceous foraminiferal genus Falsogaudryinella from northwest Europe and Romania, and its relationship to Uvigerinammina. In: Proceedings of the Fourth International Workshop on Agglutinated Foraminifera, Kraków Poland, September 12-19, 1993, (Kaminski, M.A. Geroch, S., \& Gasinski, M.A. Eds.), Grzybowski Foundation Special Publication 3, p. 145-157.

Kennedy, W.J., Walaszczyk, I. \& Cobban, W.A. 2000, Pueblo, Colorado, USA candidate Global Boundary Stratotype Section and Point for the base of the Turonian Stage of the Cretaceous, and for the base of the Middle Turonian Substage, with a revision of the Inoceramidae (Bivalvia). Acta Geologica Polonica, 50: 295-334.

Kuhnt, W., Kaminski, M.A. 1989, Upper Cretaceous deepwater agglutinated benthic foraminiferal assemblages from the Western Mediterranean and adjacent areas. In: Cretaceous of the Western Tethys. Proceedings of $3^{\text {rd }}$
International Cretaceous Symposium (Wiedmann, J., Ed.), Stuttgart, p. 93-120.

Kuhnt, W. 1990, Agglutinated foraminifera of Western Mediterranean Upper Cretaceous pelagic limestones (Umbrian Apennines, Italy, and Betic Cordillera, Southern Spain). Micropaleontology, 36 (4): 297-330.

Kuhnt, W. 1992, Abyssal recolonization by benthic foraminifera after the Cenomanian-Turonian boundary anoxic event in the North Atlantic. Marine Micropaleontology, 19: 257-274.

Lamolda, M.A., Gorostidi, A., Martinez, R. López, G. \& Peryt, D. 1997, Fossil occurrences in the Upper Cenomanian-Lower Turonian at Ganuza, northern Spain: an approach to Cenomanian-Turonian boundary chronostratigraphy. Cretaceous Research, 18: 331-353.

Leckie, R.M. 1985, Foraminifera of the CenomanianTuronian boundary interval Greenhorn Formation, Rock Canyon anticline, Pueblo, Colorado. In Fine-grained deposits and biofacies of the Cretaceous Western Interior Seaway: evidence of cyclic sedimentary processes (Pratt, L.M., Kauffman, E.G. \& Zelt, F.B., Eds.). Society of Economic Paleontologists and Mineralogists, Field Trip Guidebook 4, p. 139-150.

Leary, P.N., Peryt, D. 1991, The late Cenomanian oceanic anoxic event in the western Anglo-Paris Basin and southeast Danish-Polish Trough; survival strategies of and recolonisation by benthonic foraminifera. Historical Biology, 5 (2-4): 321-338.

Luciani, V., Cobianchi, M. 1999, The Bonarelli Level and other black shales in the Cenomanian-Turonian of the northeastern Dolomites (Italy): calcareous nannofossil and foraminiferal data. Cretaceous Research, 20: 135-167.

Murgeanu, G., Patrulius, D. 1957, Cretacicul Superior de pe marginea Leaotei şi vîrsta Conglomeratelor de Bucegi. Buletinul Ştiinţific, Secţia de Geologie şi Geografie, 11 (1): 5-21.

Murgeanu, G., Patrulius, D., Contescu, L., Jipa, D., Mihăilescu, N. \& Panin, N. 1963, Stratigrafia şi sedimentogeneza terenurilor cretacice din partea internă a curburii Carpaților. Volume of the Carpatho-Balkan Geological Association, $5^{\text {th }}$ Congress, Bucharest 1963. Guidebook Series of the Geological Institute of Romania, 3: 31-55.

Neagu, T. 1970, Micropaleontological and stratigraphical study of the Upper Cretaceous deposits between the upper valleys of the Buzău and Rîul Negru Rivers (Eastern Carpathians). Institut Géologique Mémoires, 12: 1-109.

Neagu, T., Platon, E., Dumitrescu, G. \& Selea A. 1992, The biostratigraphical significance of agglutinated foraminifera in the Eastern Carpathians (Upper Cretaceous). Analele Universităţii Bucureşti, 15-16: 45-49.

Neagu, T., Platon, E. 1994, Genera Haplophragmoides Cushman, 1910; Recurvoides Earland, 1934; Thalmannammina Pokorny, 1951; Plectorecurvoides Noth, 1952; and Pokornyammina n.gen. from Upper Cretaceous flysch facies, Eastern Carpathians, Romania. Revista Española de Micropaleontologia, 26: 5-30.

Nederbragt, A.J., Fiorentino, A. 1999, Stratigraphy and palaeoceanography of the Cenomanian-Turonian Boundary Event in Oued Mellegue, north-western Tunisia. Cretaceous Research, 20: 47-62.

Paul, C.R.C., Lamolda, M.A., Mitchel, S.F., Vaziri, M.R., Gorostidi, A. \& Marshall, J.D. 1999, The Cenomanian- 
Turonian boundary at Eastbourne (Sussex, UK): a proposed European reference section. Palaeogeography, Palaeoclimatology, Palaeoecology, 150: 83-121.

Peryt D. 2004, Benthic foraminiferal response to the Cenomanian-Turonian and Cretaceous-Paleogene boundary events. Przeglad Geologiczny, 52, (8/2): 827-832.

Robaszynski, F., Caron, M. 1995, Foraminifères planctoniques du Crètacè: commentaire de la zonation Europe-Méditerraneé. Bulletin de la Société Géologique de France, 166 (6): 681-692.

Scopelliti, G., Bellanca, A., Coccioni, R., Luciani, V., Neri, R., Baudin, F., Chiari, M. \& Marcucci M. 2004, Highresolution geochemical and biotic records of the Tethyan 'Bonarelli Level' (OAE2, latest Cenomanian) from the Calabianca-Guidaloca composite section, northwestern Sicily, Italy. Palaeogeography, Palaeoclimatology, Palaeoecology, 208: 293-317.

Săndulescu, M., Ştefănescu, M., Butac, A., Pătruț, I. \& Zaharescu, P. 1981, Genetical and structural relationship between the Flysch and Molasse (the East Carpathians model). Volume of the Carpatho-Balkan Geological Association, $12^{\text {th }}$ Congress, Bucharest 1981. Guidebook Series of the Geological Institute of Romania, 19: 3-94.

Schlanger, S.O., Jenkins, H.C. 1976, Cretaceous oceanic anoxic events: causes and consequences. Geologie en Mijnbouw, 55: 179-184.
Švábenická, L., Bubík, M., Krejčí, O. \& Stráník, Z. 1997, Stratigraphy of the Cretaceous sediments of the Magura Grup of Nappes in Moravia (Czech Republic). Geologica Carpathica, 48 (3): 179-191.

Svobodová, M., Hradecká, L., Skupien, P. \& Švábenická, L. 2004, Microfossils of the Albian and Cenomanian shales from the Štramberk area (Silesian Unit, Outer Western Carpathians, Czech Republic). Geologica Carpathica, 55 (5): 371-388.

Tocorjescu, M. 1963, Studiul micropaleontologic al depozitelor succesiunii Cretacic Superior - Paleogen de pe V. Mitoii - reg. Lăicăi. Volume of the CarpathoBalkan Geological Association, $5^{\text {th }}$ Congress, Bucharest 1963. Guidebook Series of the Geological Institute of Romania, 2: 257-293.

Tsikos, H., Jenkyns, H.C., Walsworth-Bell, B., Petrizzo, M.R., Forster, A., Kolonic, S., Erba, E., Premoli-Silva, I., Baas, M., Wagner, T. \& Sinninghe Damste, J.S. 2004, Carbon-isotope startigraphy recorded by the CenomanianTuronian Oceanic Anoxic Event: correlation and implications based on three localities. Journal of the Geological Society, London, 161: 711-719.

Varol, O. 1992, Taxonomic revision of the Polycyclolithaceae ans its contribution to Cretaceous biostratigraphy. Newsletters on Stratigraphy, 27: 93-127.

PLATE I: Figs. 1-11: SEM, Figs. 12-27: Immersion oil photographs.

Fig. 1. Nothia sp., Well-5 Holcim, 5/7

Fig. 2. Kalamopsis grzbowskii (Dylażanka), Izlaz Valley, 3/3

Fig. 3. Reophax parvulus Huss, Well-5 Holcim, 5/7

Fig. 4. Haplophragmoides falcatosuturalis Neagu, Izlaz Valley, 3/3

Fig. 5. Bulbobaculites problematicus Neagu, Izlaz Valley, 3/27

Fig. 6. Pokornyammina clara Neagu \& Platon, Well-5 Holcim, 5/4

Fig. 7. Gerochammina stanislawi Neagu, Izlaz Valley, 3/13

Fig. 8. Protomarssonella sp., Izlaz Valley, 3/27

Fig. 9. Tritaxia gaultina carinata Neagu, Izlaz Valley, 3/13

Fig. 10. Dorothia pupa Reuss, Well-5 Holcim, 5/4

Fig. 11. Ramulina novaculeata Bullard, Izlaz Valley, $3 / 3$

Figs. 12, 14. Glomospira charoides Jones\&Parker, Well-5 Holcim, 5/2

Figs. 13, 15. Glomospira charoides Jones \& Parker, Well-5 Holcim, 5/2

Fig. 16. Haplophragmoides falcatosuturalis Neagu, Well-5 Holcim, 5/4

Fig. 17. Haplophragmoides falcatosuturalis Neagu, Izlaz Valley, 3/26

Fig. 18. Haplophragmoides falcatosuturalis Neagu, Izlaz Valley, $3 / 2$

Figs. 19-21. Pokornyammina clara Neagu \& Platon, Izlaz Valley, 3/4

Fig. 22. Pokornyammina clara Neagu \& Platon, Well-5 Holcim, 5/4

Fig. 23. Gerochammina stanislawi Neagu, Izlaz Valley, $3 / 3$

Fig. 24. Gerochammina stanislawi Neagu, Izlaz Valley, 3/4

Figs. 25-27. Different specimens of Pseudobolivina sp.2, sensu Kuhnt (1992), Well-5 Holcim, 5/2 
PLATE I
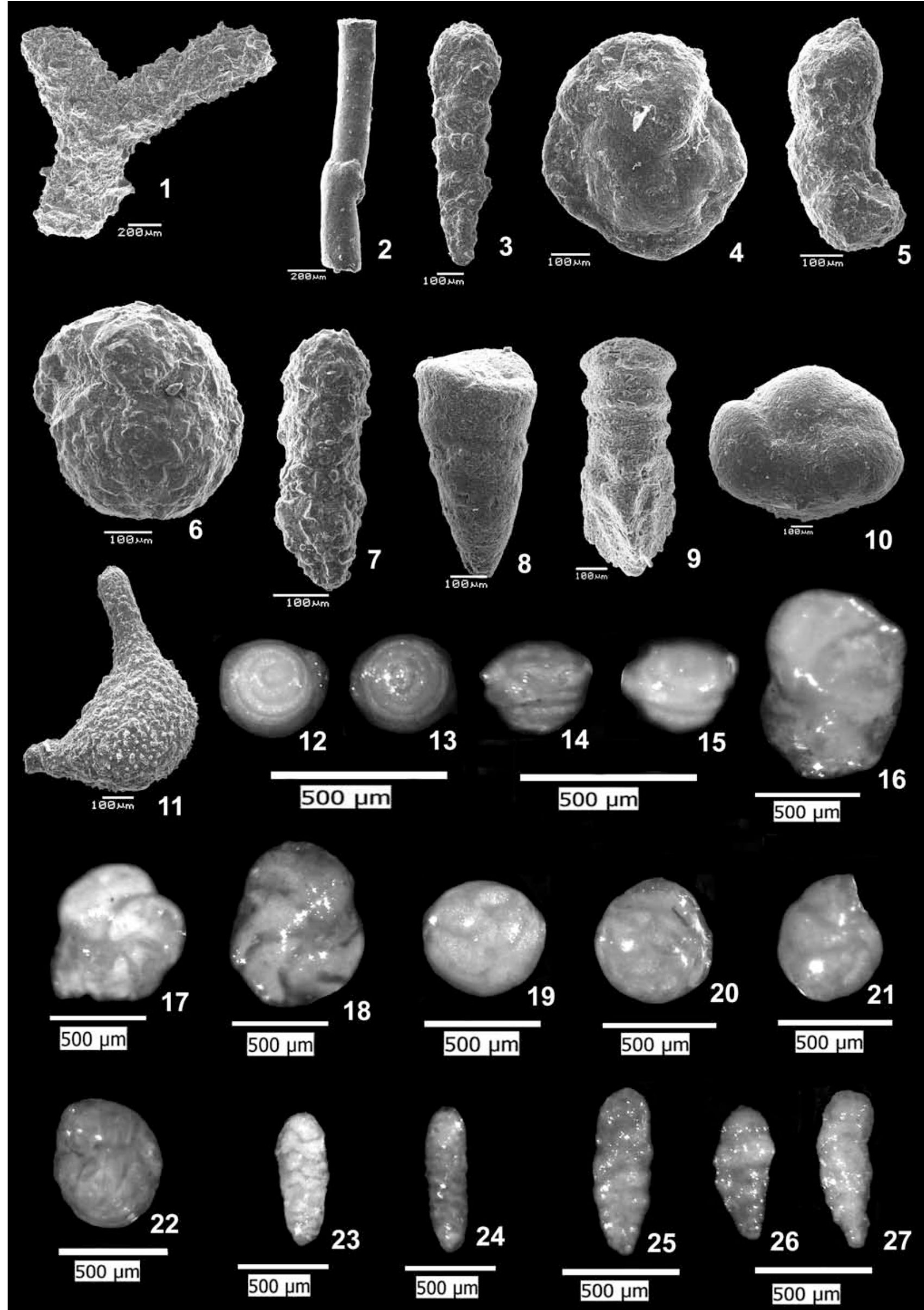


\section{PLATE II}

Figs. 1-4. Different specimens of Dicarinella cf. algeriana Caron, Well-5 Holcim, 5/1 (1 -spiral view, 2 -umbilical view, 3 -oblique lateral view, 4 -lateral view)

Figs. 5-7. Rotalipora deeckei Franke, different specimens in spiral view -5, umbilical view -6, lateral view -7, Izlaz Valley, 3/1

Figs. 8-9. Different specimens of Rotalipora cushmani Morrow, 8-spiral view, 9 -umbilical view, Izlaz Valley, 3/1

Figs. 10-12. Different specimens of Rotalipora cushmani Morrow, 10-spiral view, 11 -umbilical view, 12 - lateral view, Well-5 Holcim, 5/4

Figs. 13-15. Different specimens of Rotalipora gandolfii Luterbacher \& Premoli Silva, 13 - spiral view, 14 -umbilical view, 15-lateral view, Well-5 Holcim, 5/9

Figs. 16-18. Rotalipora brotzeni Sigal; 16 - spiral view, 17 -umbilical view, 18 - lateral view, Well-5 Holcim, 5/9 
PLATE II

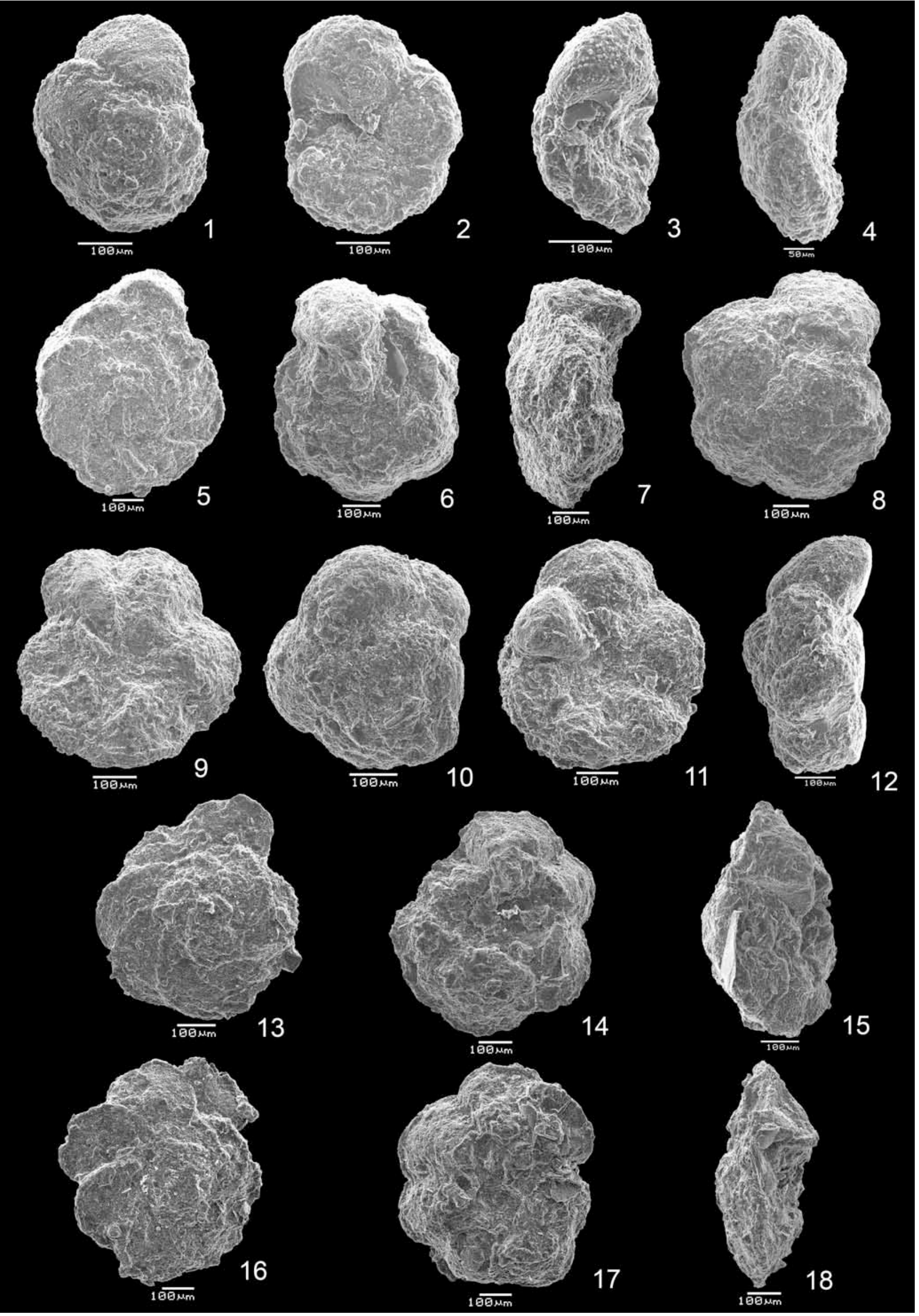

Studia UBB, Geologia, 2008, 53 (1), 11 - 23 


\section{PLATE III}

Figs. 1-6. Planktonic foraminifera

Figs. 1-3. Different specimens of Whiteinella paradubia Sigal, 1 -spiral view, 2 -umbilical view, 3 -lateral view, Izlaz Valley, $3 / 12$

Figs. 4-6. Different specimens of Whiteinella brittonensis Loeblich \& Tappan, 4-spiral view, 5 -umbilical view, 6-lateral view, Izlaz Valley, 3/12

Figs. 7-18. Calcareous nannofossils

Fig. 7. Axopodorhabdus albianus $(x$ 3000)

Fig. 8. Biscutum constans $(x$ 3000)

Fig. 9. Cretarhabdus conicus $(x$ 3000)

Fig. 10. Cylindralithus biarcus $(x$ 2000)

Fig. 11. Eprolithus floralis $(x 3000)$

Fig. 12. Eprolithus octopetalus $(x$ 3000)

Fig. 13. Eiffelithus turriseiffelii $(x$ 3000)

Fig. 14. Microrhabdulus decoratus (x 2000)

Fig. 15. Prediscosphaera columnata (x 3000)

Fig. 16. Quadrum gartneri $(x$ 2000)

Fig. 17. Watznaueria barnesiae (x 3000)

Fig. 18. Rhagodiscus achlyostaurion (x 3000) 
PLATE III
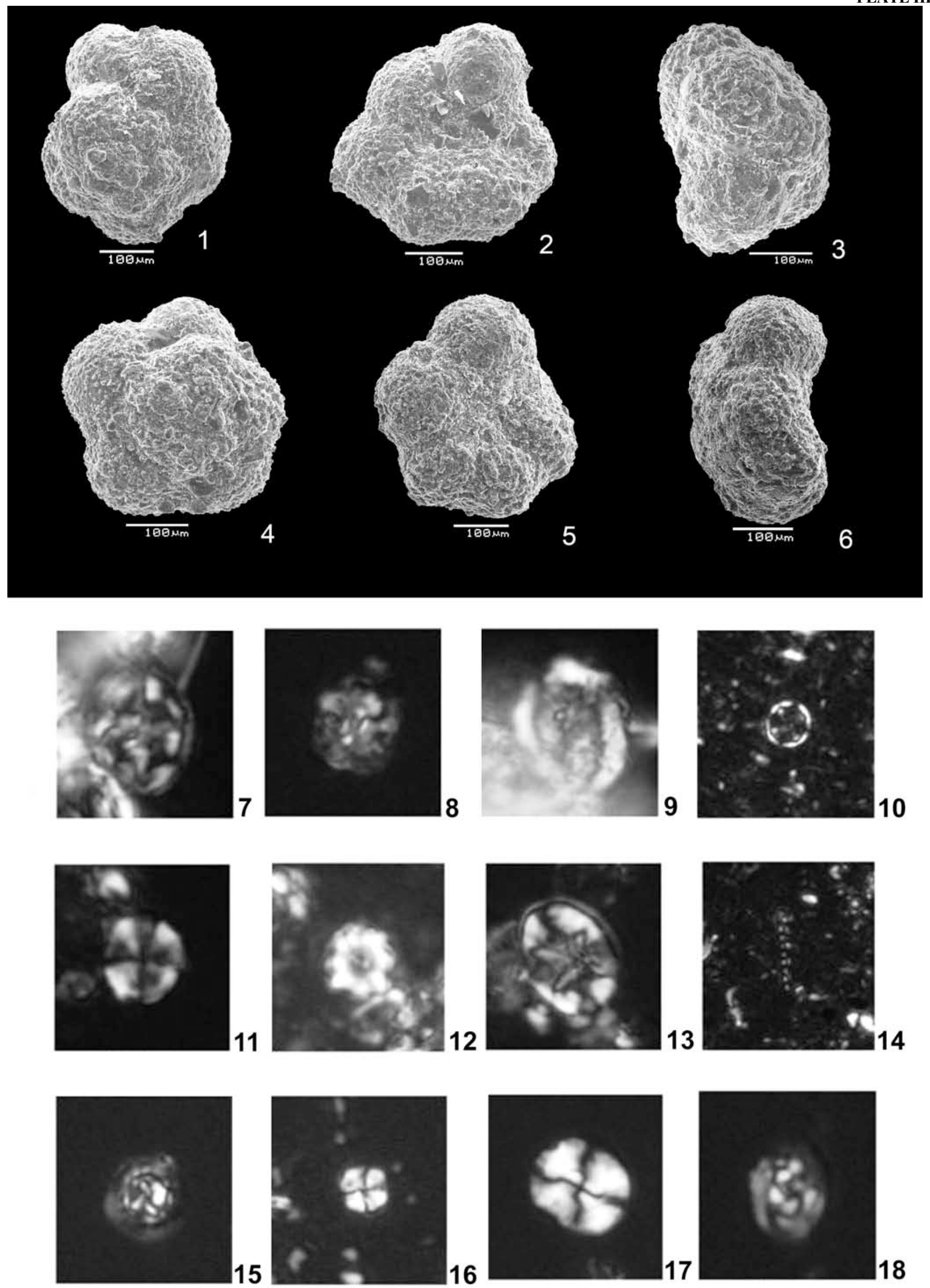